\title{
Theeran Chinnamalai: Hero of the First Phase of Freedom Struggle in Erode District
}

\author{
S . Jothimani* \\ Assistant Professor of History, Vellalar College for Women, Erode - 638012, \\ Tamil Nadu, India; \\ sjothi.1977@gmail.com
}

\begin{abstract}
From the $18^{\text {th }}$ century onwards Erode district has lent a number of brave and great personalities for the country. They had rendered their invaluable service to the society and country. Among them, in the late $18^{\text {th }}$ and $19^{\text {th }}$ century, Theeran Chinnamalai was an important personality who was a great opponent of the British in Coimbatore and Erode areas. Numerous leaders tried their best to awaken the people of India. The struggle ensued of uncountable sacrifices.
\end{abstract}

Keywords: Freedom Struggle, Kongu Mandalam, Kongu Padai, Kovai Puratchi

\section{Introduction}

I India is the largest democratic country in the world. India, with its huge population of different castes and creed stands as a unique country in the world for its unity in diversity. At present India holds an important position in the world's comity of nations. From the 16th century to the early part of the $20^{\text {th }}$ century, India with a complement of several Princely States had to suffer from foreign invasions and lastly from the British rule, subjugating itself to the aliens way of life in their political, social, economic and religious pursuits. From the $18^{\text {th }}$ century onwards, Indians came to realize their enslavement under the British rule. Numerous leaders tried their best to awaken the people of India. The struggle ensued of uncountable sacrifices.

\section{Objectives}

- To bring out the role of Erode District in the freedom struggle.

${ }^{*}$ Author for correspondence
- To understand Theeran Chinnamalai's contributions towards freedom movement.

- To identify Theeran Chinnamalai as an inspiration to the patriots of Erode.

- To enlighten the heroic deeds of legendary freedom fighter.

\section{Methodology}

The narrative and analytical method has been used to the present study. Both primary and secondary sources are extensively used. It critically examines the contributions made by Theeran Chinnamalai in the freedom movement.

Erode District which has been carved out of Coimbatore district in 1979 has been flourishing in agriculture, handloom industry, art and culture ${ }^{1}$. During the $18^{\text {th }}$ century, while the British East India Company was trying to establish its supremacy and over lordship all 
over India, a small portion of land covering Erode town and its surrounding areas in the southwest remained independent under a gallant warrior, popularly known as "Theeran Chinnamalai". The heroic warrior waged three wars against the British forces successfully and the British East Indian Company could not advance against him victoriously. The British forces had to adopt other infamous, dubious means only to capture the warrior and establish their rule. Thus Theeran Chinnamalai was the first hero of this part of the area who fought for the land of the natives. Later on, as the political, economic and social enslavement of India was made complete by the British Empire, an organized freedom struggle at the national level became a historic necessity. It was percolating down the farther areas among which Erode District had contributed more vehemently to the cause of freedom by its great personalities.

The patriots of Erode and surrounding areas who were inspired by the legendary heroism of Theeran Chinnamalai embarked on the struggle with a selfless motive. Every struggle at the national level had its parallel action in Erode District. The contribution of these brave freedom fighters of Erode District deserves due recognition and remembrance.

From the $18^{\text {th }}$ century onwards Erode district has lent a number of brave and great personalities for the country. They had rendered their invaluable service to the society and country. Among them, in the late $18^{\text {th }}$ and earlier $19^{\text {th }}$ century, Theeran Chinnamalai was an important personality who was a great opponent of the British in Coimbatore and Erode areas. Theerthagiri was the second son of Rathinasarkarai and Periyaathaal. He was born in 1756 who was later called Theeran Chinnamalai. His family lived in a place called Melappalayam nearer to Arachalur just 23 kilometers away from Erode. On those days, Mysore King ruled the Kongu Mandalam and the king used to collect the taxes of Kangeyam and Dharapuram areas. Once when the amount was being taken to the Dewan of Sankagiri for being paid to the Mysore King, Theeran and his brothers objected to it and captured the booty. They distributed the money to the poor. When asked by the guards who were on the duty of carrying the taxes, about his name, he answered "This is Chinnamalai in between Sivanmalai and Chennimalai and this warrior of Kongunadu has taken over the amount". From this incident Theeran was called Chinnamalai ${ }^{2}$. The soldiers of the Mysore king stationed at Sankagiri were sent to fight against Theerthagiri and the soldiers of Mysore ran helter-skelter for life unable to bear the humiliating defeat at the hands of Theerthagiri. After this incident, Chinnamalai started to make a small army for him to fight against the British. He included the Palayatthu people who were in the same thought.

On 7 December 1782, Hyder Ali had died and Tippu Sultan gained the crown of Karnataka and led the freedom struggle in a stronger way. At that time the Kongu Mandalam (a vast area now comprising of the districts of Coimbatore, Erode, Karur, Salem, Namakkal and Dharmapuri), which was under the rule of Mysore King, was also brought under Tippu Sultan. Tippu Sultan by then learnt about the heroic warriorship of Theeran Chinnamalai and about the aspirations of this warrior to fight against the British to whom the Indian rulers were forced to obey ${ }^{3}$.

Both Tippu Sultan and Chinnamalai had felt that their common enemy was the British and hence decided to fight and conquer the British with more men and weapons. Tippu was in need of soldiers for his troops. Chinnnmalai motivated more number of people to join Tippu's troop. From 18 April 1792 onwards, Chinnamalai started giving training for the soldiers at forests. He made weapons for use in the war. Chinnamalai had taken thousands of soldiers to Mysore for devising strategic ways to fight the British army. At that time the French soldiers under the Jacobin group were there. They used to give vigorous training to the 'Kongu Padai' (Kongu army) which was led by Chinnamalai ${ }^{4}$.

On those days, Coimbatore was an important place in Kongunadu. In the middle of the 18th century, Mysore Kings Samaraja Udayar and then Krishnaraja Udayar ruled the place. On behalf of them, Kumara Devaiyyan and Kurikkaara Madhaiyyan ruled Coimbatore. Later when Hyder Ali and Tippu became rulers, Coimbatore went under their control. In the Third Mysore War, 
Coimbatore went into the hands of the British East India Company. A British battalion was stationed in the Coimbatore Fort. Native chieftains slowly understood that Coimbatore under the British East India Company would be a great danger for them. They planned to capture Coimbatore under the leadership of Chinnamalai ${ }^{5}$.

In the Fourth Mysore war Chinnamalai's army fought at the places like Malavalli, Seerangapattanam and Chitheshwaram and inflicted heavy losses on the British troops. But Chinnamalai had to return to his native due to the death of Tippu Sultan in the battle of 1799. But Chinnamalai continued his activities, built a fort in 'Oada Nilai' and added strength to his troops. According to the Seerangapattanam agreement, though Kongunadu was under the control of the British East India Company, a vast area of Chinnamalai, lying in between Sankagiri and Coimbatore remained as an independent one under the control of Theeran Chinnamalai. So the British East India Company planned to capture it as it constituted a missing link between Madras (Chennai) and Malabar-Calicut in the northern part of this province ${ }^{6}$.

Theeran Chinnamalai who knew the designs of the British decided to crush the foreign dominance and attack the Coimbatore fort on 3 June 1800. The British troops stationed at Coimbatore Fort had more number of Muslim soldiers. So Theeran Chinnamalai planned to fix the attack on the date of Moharam which is one of the important functions of Muslims. In February 1800, soliders of Chinnamalai's army went to Coimbatore and started to live among people as one among themselves. To help Chinnamalai, Oaru Bathe Mohammed, Ichhipatti Ulla Khan and Osur Kani Jahan reached Coimbatore with four thousand horses. Persons like Varanavasi from Poondurai, Vellai Gounder from Erode, Kumara Vellai from Perundurai and Periya Thambi from Aravakurichi, who were Chinnamalai's friends also reached Coimbatore to help Chinnamalai. Appachi Gounder and Neelappa Gounder from Salem also joined the struggle. Certain soldiers because of their great interest started their work on the previous day of Moharam itself. Meantime the Thasildar of Coimbatore noticed the activities of some strange people and he understood the impending attack on the Coimbatore Fort planned by Theeran Chinnamalai. He passed on the message as earlier as possible to General Mclister, the Commander of the British army. By this timely alert, the proposed revolution was crushed, forty two native soldiers were hanged and several others were deported to the Island of Prince of Wales. The above news spread throughout the area. Thus the 'Kovai Puratchi' met a negative result on 8 June $1800^{7}$.

Yet Chinnamalai was never frustrated or demoralised by the defeat of 'Kovai Revolution' (Kovai Puratchi). He started to strengthen his fort at Oada Nilai. Realising the popularity and the potent force of Theeran Chinnamalai, the British East India Company decided to conclude an agreement with him and deputed a local native officer for the purpose. The agreement was that if Theeran Chinnmalai allowed the British East India Company to rule Chinnamalai, by accepting their supremacy, he himself could be the sole leader of this area and that he should pay $30 \%$ of the taxes collected to the British East India Company annually. Chinnamalai strongly rejected such an agreement and opposed foreign rule outright. So the British planned a war against Chinnamalai. The British waged three wars against Chinnamalai. The first war was in 1801 on the banks of the river Cauvery, the second one in 1802 at Oada Nilai and the third in 1804 at Arachalur, in all of which tremendous victory was on the side of Chinnamalai. The British Colonel Maxwell was killed by the sword of Theeran Chinnamalai in the battle of Oada Nílai ${ }^{8}$

Thus the British were totally upset about Theeran Chinnamalai's strength and power. So they planned to capture him cunningly in 1805. A charlatan, who worked under Theeran Chinnamalai as a cook deceived him by informing his abode to the British.

The British arrested Chinnamalai by their slyness, brought him to Sankagiri and hanged him on 31 July 1805. The British canons destroyed his Oada Nilai fort $^{9}$. 


\section{Conclusion}

Theeran Chinnamalai sowed the seeds of freedom movement in the future years and his heroic struggle against the British in this part of Kongumandalam became a source of inspiration for the later generations. Thus he was the first man in Erode district to fight an organized war against the British imperialism even before the massbased formation of the Indian National Congress.

\section{References}

1. Baliga BS. Coimbatore District Gazetteer; Coimbatore. 1966. p. 56.

2. Rasu.S. Vellaiyarai Yethirthu Verappor Purindha Theeran Chinnamalai Gounder. Chennai; 1996. p. 23.
3. Rasu S. Vellaiyarai Yethirthu Verappor Purindha Theeran Chinnamalai Gounder. (Tamil) Chennai; 1996. p. 23.

4. Stalin Gunasekaran T. Viduthalai Velviyil Tamizhagam. (Tamil) Erode. 2000; Vol. I, p. 101.

5. Stalin Gunasekaran T. Desa Viduthalaiyum Thiyaga Sudarkalum, Chennai; 1988. p. 121.

6. Seetharam Singh M. Periyar Mavata Sudhanthira Porata Varallaru. Erode; 1986. p. 13.

7. Seetharam Singh M. Periyar Mavata Sudhanthira Porata Varallaru. Erode; 1986. p. 13.

8. Stalin Gunasekaran T. Viduthalai Velviyil Tamizhagam. Erode; 2000; Vol. I, p. 105.

9. Rasu S.Vellaiyarai Yethirthu Verappor Purindha Theeran Chinnamalai Gounder. Chennai; 1996. p. 102. 